\title{
KARST GEOMORPHOLOGY, CAVE DEVELOPMENT AND HYDROGEOLOGY IN THE KASHMIR VALLEY, WESTERN HIMALAYA, INDIA
}

\author{
KRAŠKA GEOMORFOLOGIJA, RAZVOJ JAM \\ IN HIDROGEOLOGIJA V KAŠMIRSKI DOLINI, \\ ZAHODNA HIMALAJA, INDIJA
}

\author{
Rouf Ahmad SHAH ${ }^{1}$, Ghulam JEELANI ${ }^{1, \star} \&$ Nico GOLDSCHEIDER ${ }^{2}$
}

\begin{abstract}
UDC 551.4:556.3(235.243)(540.11)

Rouf Ahmad Shah, Ghulam Jeelani \& Nico Goldscheider: Karst geomorphology, cave development and hydrogeology in the Kashmir valley, Western Himalaya, India

Surface and underground karst features, such as karren, dolines, sinking streams, caves and large freshwater and thermal springs are developed in Triassic Limestone in the southern Kashmir Valley. The rock formation has a high hydraulic conductivity (K), up to $1,000 \mathrm{~m} \mathrm{~d}^{-1}$ and constitutes one of the most productive aquifers in the region. Springs discharging from this aquifer supply pristine water to more than one million people, but the regional karst system is still poorly understood. The present study is really a first and preliminary study of an important but remote and previously unstudied area, with the goal to provide a first overview and inventory of karst phenomena, as a basis for more detailed (and more "scientific") studies in the future. Results suggest that karstification is developed along tectonic joints and bedding planes. Karstification shows distinct variation with altitude and is more developed towards the valley floor. The study also revealed that erosion of the alluvium along streams pushed karstification downwards and caused drying up of formerly phreatic cave passages. Reconstruction of karst evolution on the basis of geomorphological, geological and climatic conditions of the region suggests that karstification has started during Plio-Pleistocene. The present surface and subsurface karstification is directly related to the tectono-sedimentational history of the Himalaya and the climatic conditions that prevailed after the Himalayan Orogeny.

Key words: Triassic Limestone, karstification, freshwater supply, Himalaya, Kashmir Valley.
\end{abstract}

Izvleček UDK 551.4:556.3(235.243)(540.11)

Rouf Ahmad Shah, Ghulam Jeelani \& Nico Goldscheider: Kraška geomorfologija, razvoj jam in hidrogeologija $v$ Kašmirski dolini, Zahodna Himalaja, Indija

Površinske in podzemne kraške oblike, kot so škraplje, vrtače, reke ponikalnice, jame ter veliki sladkovodni in termalni izviri, so v južni Kašmirski dolini nastale v triasnih apnencih. Ti imajo visoko hidravlično prevodnost (K) do $1000 \mathrm{~m} \mathrm{~d}^{-1}$ in so med najbolj produktivnimi vodonosniki v regiji. Izviri, ki drenirajo ta vodonosnik, prispevajo neoporečno vodo več kot milijon ljudem. Kljub temu hidrogeologijo regionalnega kraškega sistema še vedno slabo razumemo. Ta študija je prva in preliminarna študija pomembnega, a oddaljenega in predhodno neraziskanega območja ter poskuša zagotoviti prvi pregled in popis kraških pojavov kot podlaga za podrobnejše (in bolj »znanstvene«) študije. Rezultati kažejo, da je zakrasevanje razvito vzdolž tektonskih prelomov in lezik. Zakrasevanje se razlikuje glede na nadmorsko višino in je bolj razvito proti dnu doline. Študija je pokazala tudi, da je erozija aluvija vzdolž vodotokov potisnila zakrasevanje $\mathrm{v}$ globino vodonosnika in povzročila fosilizacijo predhodno freatičnih jamskih kanalov. Rekonstrukcija kraškega razvoja na podlagi geomorfoloških, geoloških in klimatskih razmer v regiji nakazuje, da se je zakrasevanje začelo med Plio-Pleistocenom. Sedanje površinsko in podzemno zakrasevanje je neposredno povezano s tektonsko-sedimentacijsko zgodovino Himalaje in podnebnimi razmerami, ki so prevladovale po himalajski orogenezi.

Ključne besede: triasni apnenec, zakrasevanje, oskrba z vodo, Himalaja, dolina Kašmir..

\footnotetext{
${ }^{1}$ Department of Earth Sciences, University of Kashmir, Srinagar-190006, India, e-mails: roufulshah@gmail.com; geojeelani@ gmail.com

${ }^{2}$ Karlsruhe Institute of Technology (KIT), Institute of Applied Geosciences (AGW), Division of Hydrogeology, Kaiserstrasse 12,

76131 Karlsruhe, Germany, e-mail: goldscheider@kit.edu

* Corresponding author
}

Received/Prejeto: 05.08.2018 


\section{INTRODUCTION}

Within the realm of geomorphology each geomorphic process leaves a distinct assemblage of landform (Thornbury 1969), and for a karst, this imprint is expressed as solutional morphology. Karst is a landscape, characterised by well-developed subsurface drainage network, formed from the dissolution of carbonates (Culver \& White 2005; Ford \& Williams 2007; Nohegar et al. 2012), evaporites (Klimchouk 2002; Jeelani \& Shah 2016) and to lesser extent quartzites (De Waele et al. 2009), and siliceous sandstones (Martini 2000). These landscapes are usually recognized in the field by the presence of diagnostic surficial (exokarst) geomorphic and hydrologic features, such as karren, dolines, sinkholes, poljes and large springs with high discharge variations (Bögli 1980; Field 2002; Ford \& Williams, 2007; Stokes et al. 2010), and by characteristic subsurface features (endokarst), such as conduits, caves (sometimes with speleothems) and subsurface streams (Bögli 1980; Palmer 1991; Field 2002; Ford \& Williams 2007). As rate of solution/dissolution activity varies with the climate, topography, lithology, biogenic activity and structural characteristics, thus a great diversity of geomorphic and hydrologic features of varied degree, exist on karst landscapes worldwide (Herak \& Stringfield 1972; Ford \& Williams 2007).

Globally, karst topography is found at all latitudes and elevations, and cover a substantial portion (15$20 \%$ ) of the Earth's land surface (Ford \& Williams 2007; Goldscheider \& Chen 2017). These landscapes represent Earth's most diverse, scenic and resource-rich terrains and offer many opportunities for scientific, educational research and recreational benefits (Mylroie \& Mylroie 2007; Hall \& Day 2011; Nohegar et al. 2012). Furthermore, karstic rocks are the most important and productive hydrogeological formations (Bakalowicz 2005; Goldscheider et al. 2010). Karst aquifers contribute substantially to freshwater and thermal water supplies in many regions of the world (Chen et al. 2017). Nearly $40-50 \%$ of the human population utilizes drinking water derived from karst aquifer systems either directly or indirectly (COST ACTION-65 1995; Brinkmann \& Parise 2012). Furthermore, thermal water resources are chiefly used for bathing and geothermal energy in most countries (Goldscheider et al. 2010).

As karst geomorphology and karst hydrogeology are closely linked (Goldscheider \& Drew 2007; De Waele et al. 2009) unique hydrologic, geomorphic and hydrogeologic features of karst thus, make karst aquifer systems highly vulnerable to pollution and contamination (Vesper et al. 2001; Zwahlen 2004; Gunn 2007; North et al. 2009; Chen et al. 2017), and make them difficult to manage (Stevanović 2015). Understanding the geological structure, the landscape evolution (e.g., the history of karstification), the geomorphological characteristics and delineating the catchment and actual source areas is therefore, an important basis for karst groundwater resources management and to implement the protection schemes in karst areas (Zwahlen 2004; Goldscheider 2005).

Very little information is available on the karst geomorphology of Kashmir Valley in India (e.g., Coward et al. 1972; Jeelani 2005). The limited studies carried out so far provide important information on the hydrology of this region, but knowledge of the surface and subsurface karstification and the aquifer properties is still inadequate. The present study is really a first and preliminary study of an important but remote and previously unstudied area, with the goal to provide a first overview and inventory of karst phenomena, as a basis for more detailed (and more "scientific") studies in the future. It aims to understand the karstification process and to develop a karst geomorphological evolutionary history of the area, as a basis for a better management of the valuable karst groundwater resources in the Kashmir Himalaya. In addition, the present study will provide an important karst and speleological database to less familiar karst region of the Indian subcontinent.

\section{STUDY WORKFLOW}

Field work has been carried out from November 2012 to July 2014 for mapping the carbonate lithology and for the identification and characterization of surface and subsurface karst geomorphic and hydrologic features. The key approaches adopted for achieving the goal of the present research work are illustrated in Fig. 1. The lithologi- cal, structural and geomorphic data collected in the field were analysed using ESRI ArcGIS 9.3 and Eradas Imagine 9.1 software in order to prepare a karst geomorphic map of the area. Some earlier reported lithological maps of Middlemiss (1910) and Coward et al. (1972) were also used. 


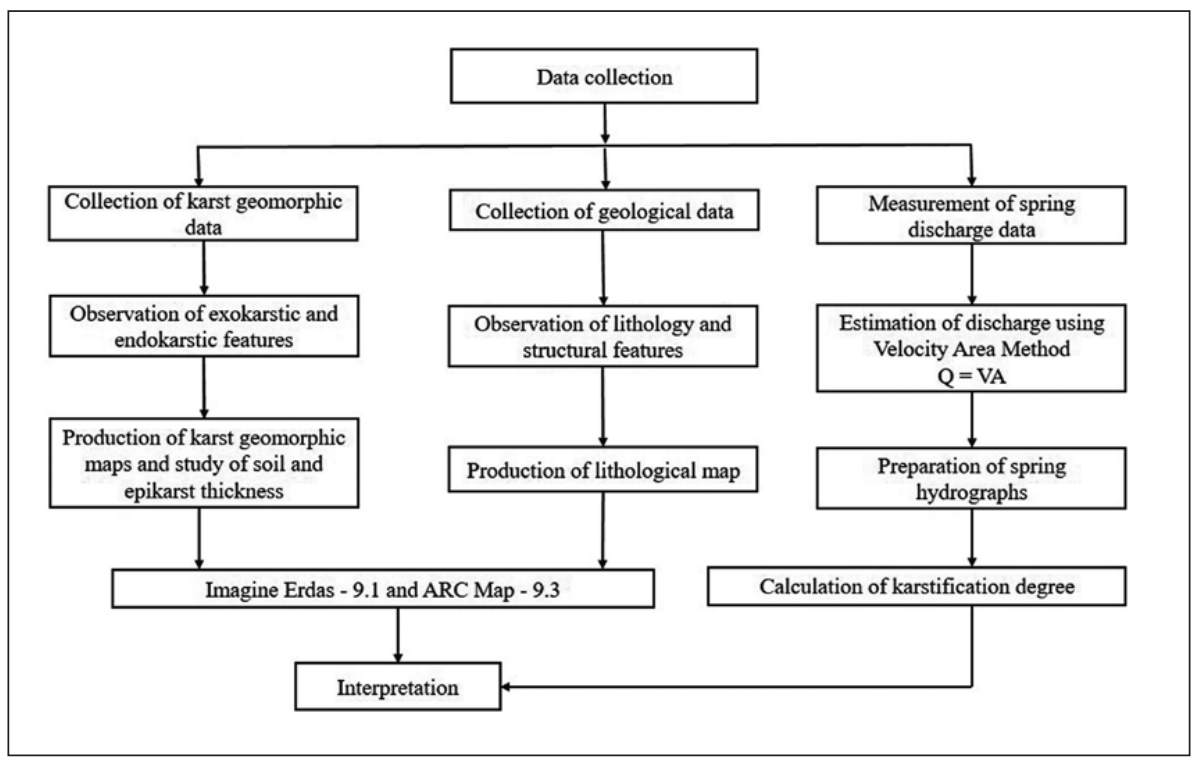

Fig. 1: Flow chart showing key approaches used in present study.

\section{OVERVIEW OF THE STUDY AREA}

The study area covers an area of $2402 \mathrm{~km}^{2}$, including four mountainous catchments (Liddar, Kuthar, Bringi and Sandran), and belongs to one of the largest karst regions on the Indian subcontinent and the Himalaya region (Fig. 2). The altitude of the catchments ranges from $1600 \mathrm{~m}$ above sea level (m a.s.l.) to $5200 \mathrm{~m}$ a.s.l. The climate shows a great variability and marked seasonality in te mperature and precipitation. Monthly air temperatures measured at Pahalgam weather station (latitude: $34^{\circ} 01^{\prime} \mathrm{N}$, longitude: $75^{\circ} 19^{\prime} \mathrm{E}$ and elevation: $2132 \mathrm{~m}$ a.s.l.) ranges from $35^{\circ} \mathrm{C}$ in summer to $-15^{\circ} \mathrm{C}$ in winter. March normally receives the maximum rainfall of the year $(183 \mathrm{~mm})$ and November the least $(36 \mathrm{~mm})$. The precipitation is dominantly in the form of snow in winter and early spring, whereas rain prevails for the rest of the year (Jeelani et al. 2016, 2017). The geology of the study region preserves a record of the Himalayan Orogenesis and the subsequent sedimentary and volcanic processes (Fig. 3). Paleozoic rocks include sandstone, siltstone, mudstone and shale (Lower Paleozoic), quartzites (Muth
Quartzite), grey limestone, quartzite and shale (Syringothyris Limestone), quartzite and shale (Fenestella Shale), pyroclastic slates, conglomerate, quartzite and porphyry granites (Agglomeratic Slate), andesitic and basaltic lavas with amygdaloidal and glomeroporphyritic texture (Panjal Traps), cherts, calcareous and siliceous shales, limestones and quartzites (Gangamopteris Beds) which occur mostly towards the marginal areas. Triassic Limestone overlies the Paleozoic rocks and occurs in the form of dissected ridges in the study area. The Triassic sequence consists of compact blue limestone, argillaceous limestone and dolomitic limestone intercalated with sandstone and shale (Middlemiss 1910). The Pleistocene Karewa deposits consist mostly of sand, conglomerates and loess. Small valleys between Triassic Limestone ridges and Karewa deposits are filled with Recent Alluvium (Fig. 3). Visible groundwater discharge occurs via karst springs, generally located at the contact between Triassic Limestone and alluvium (Jeelani 2008).

\section{DISTRIBUTION OF CARBONATE ROCKS AND KARST LANDFORMS}

Kashmir Valley underwent an intricate and complex geological (Ganju \& Khar 1984) and geomorphological evolution (Dar et al. 2014; Alam et al. 2015), and provides significant karst geomorphic imprint due to the wide distribution of carbonate rocks, particularly towards the southern fringe of the region (Fig. 2). The diversity of surface karst features, among which some imply the existence of a well-developed subsurface karst, have created a unique landscape. The dissolution of carbonate rocks and the subsequent development of parks designed at the 
spring outlets, has led to label these karst areas as state parks which features the region a very popular holiday destination. Karstified carbonate rocks cover an area of about $1100 \mathrm{~km}^{2}$ in Kashmir Valley, of which $58 \%$ (631 $\mathrm{km}^{2}$ ) lie in the southern part of the valley. The Triassic Limestone constitutes significant karst geomorphologic imprints including solutional features, swallow holes, conduits, shafts, caves and large springs. This carbonate rock formation has a high hydraulic conductivity, up to $1000 \mathrm{~m} \mathrm{~d}^{-1}$ (Jeelani 2008), and represents a major hydrogeological unit and a regionally important groundwater reservoir.

The karst areas occur in the form of dissected ridges and are well distributed in Verinag area $\left(250 \mathrm{~km}^{2}\right)$, followed by Kokernag $\left(>170 \mathrm{~km}^{2}\right)$, Achabal $\left(85 \mathrm{~km}^{2}\right), \mathrm{Za}-$ jibal-Sheshnag transect $\left(70 \mathrm{~km}^{2}\right)$, Mattan $\left(47 \mathrm{~km}^{2}\right)$ and Anantnag areas $\left(9 \mathrm{~km}^{2}\right)$ (Fig. 3). Each carbonate karst ridge exhibits peculiar exokarst and endokarst features with their own distinctive characteristics. These characteristics are largely imposed by the structural development and the relationships between lithology and topography. It is pertinent to note here that much of the carbonate ridges (Triassic Limestone surfaces) are covered with the thick Quaternary fluvio-glacio-lacustrine Karewa deposits that have restricted the exposure of most surface karst geomorphic features. Large karst springs, including both cold and warm springs, are the prominent hydrological karst features in the Kashmir Valley, though diverse types of surface karst features are also developed on a wider range and on different scales. Mechanical weathering (frost shatter) prevails at elevations between 3000-3500 $\mathrm{m}$ a.s.l., while chemical weathering (pitting, rillenkarren, and caverns) is dominant in lower elevations. The surficial and subsurface karst geomorphic features identified in the study region are described in detail below.

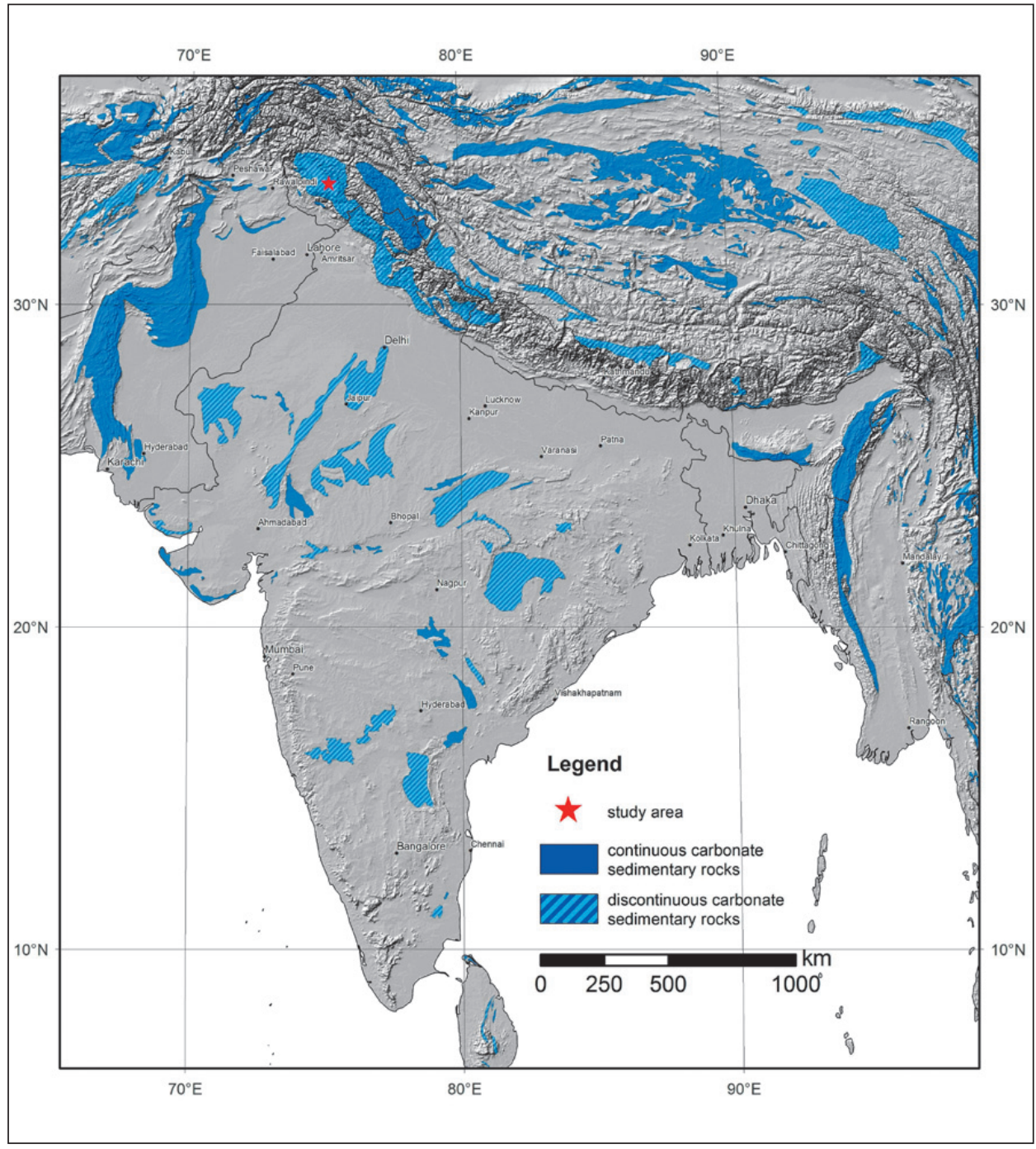

Fig. 2: First karst aquifer map of the Indian subcontinent and the Himalaya region, with location of the study area. The map is a detail of the World Karst Aquifer Map (Source: Chen et al. 2017). 


\section{SURFACE KARST GEOMORPHIC FEATURES}

\section{SOIL AND EPIKARST}

Soil and epikarst plays a vital role in the hydrology of karst regions (Williams 2008). The thickness of soil and epikarst in the study region follows the local surface topography and occurs at variable thickness above the vadose zone (Tab. 1). Fig. 4 presents different types of surficial karst features and epikarst development in the study area. The intensity of weathering in the epikarst was observed to be higher in areas covered with soil and dense vegetation, probably due to increased $\mathrm{CO}_{2}$ partial pressures produced by biogenic processes. At some places, the thickness and properties of epikarst and soil could not be measured due to security reasons (e.g., Anantnag, Mattan, and Kokernag karst areas). The content of biogenic acids and humidity concentration in the pedological layer seems to have strong influence on the epikarst development. This can be best evidenced towards north-east Mattan, Anantnag and south-west Achabal and Kokernag karst areas.

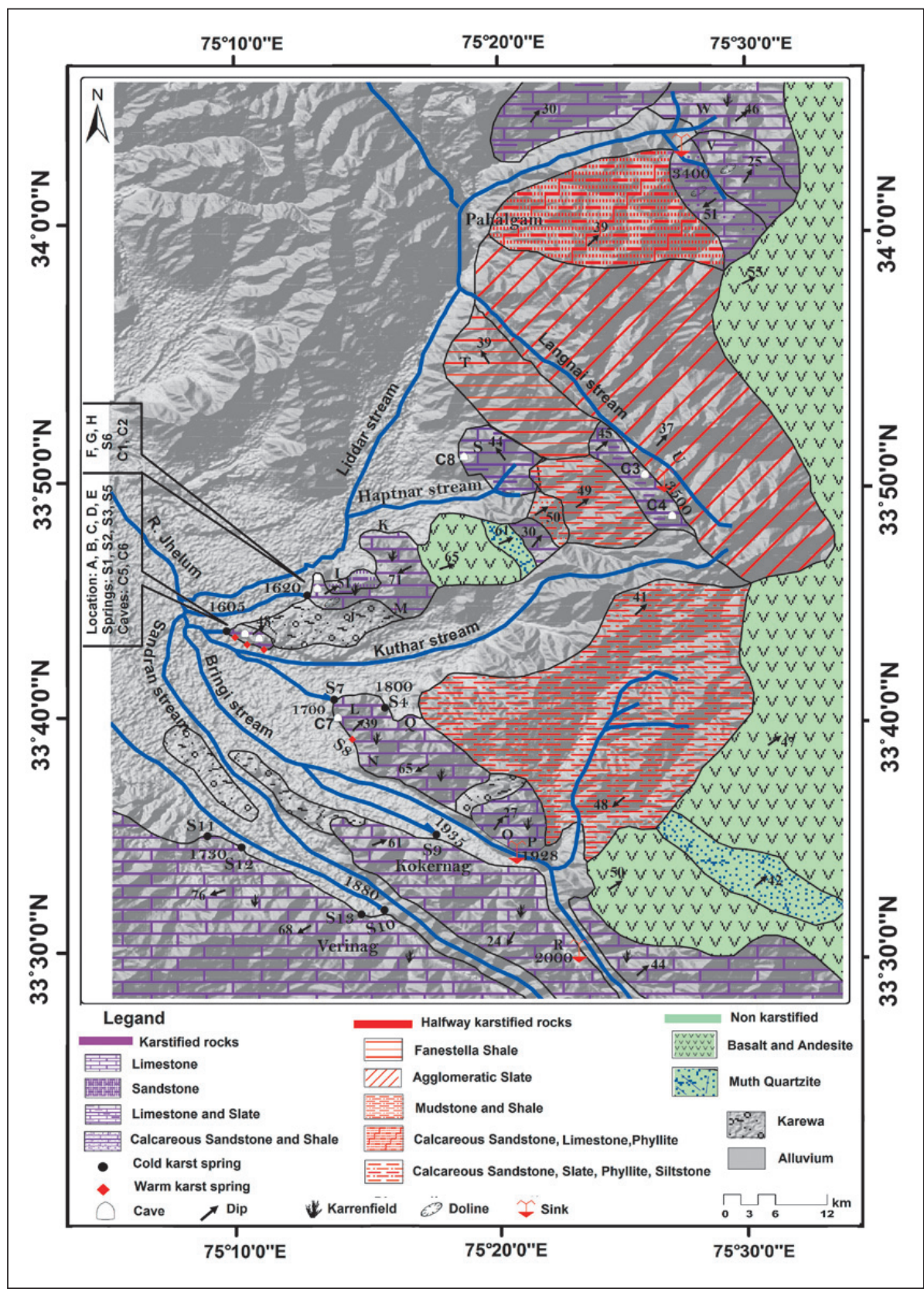

Fig. 3: Geological and Karst Map of the study area showing lithostratigraphic units, caves, springs, and stream sinks. The Liddar, Kuthar, Bringi and Sandran catchment streams are also shown in the map (modified after Coward et al. 1972). 


\section{KARREN}

Karren represent a complex group of small to mediumsized karstic landforms showing a great variety of characteristic shapes, and act as major recharge areas feeding the epikarst (Ginés et al. 2009; Plan et al. 2012). Analyzing karren features can help to reconstruct landscape development and past climatic conditions (Radulović 2013). Karren are common but sparsely distributed over the study area. Karrenfields of different sizes and shapes which include rillenkarren, rinnenkarren, grikes, rundkarren, and rain pitting (Figs. 5, 6) were observed on the plateaus and ridges at various locations/villages (Figs.
5, 6). Well-developed karrenfields are exposed in areas without soil cover. However, the thick soil cover seems to have hidden most of surface karst features. Details of the different karren types are described in the following sections.

\section{RILLENKARREN}

Rillenkarren are the most widely distributed solutional features in the study region. These features were identified at an altitude range of 1600 to $2600 \mathrm{~m}$ a.s.l. and 3000 to $3500 \mathrm{~m}$ a.s.l., and developed on slopes ranging from 35 to $45^{\circ}$. Notable dimensional contrast has been found
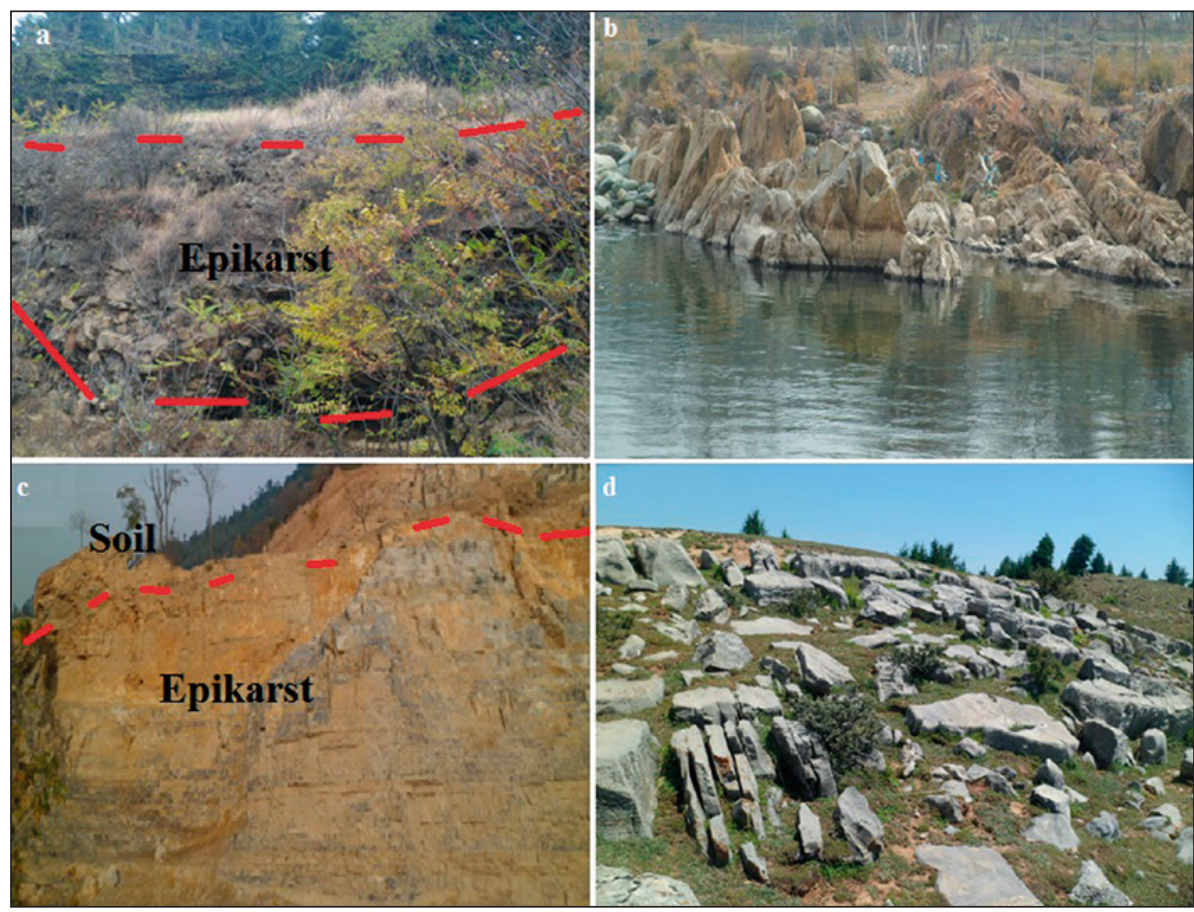

Fig. 4: Development of epikarst at different locations/villages of the study region; (a) Shairbagh (b) Dailgam (c) Khanmohalla (d) Keherbal (Photo: R. A. Shah).

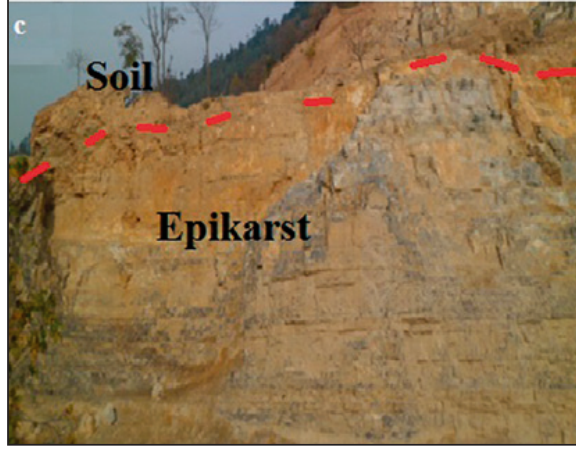

Tab. 1: Some characteristics of soil and epikarst thickness in the study area. Presented locations are shown in Fig. 3.

\begin{tabular}{|c|c|c|c|c|c|c|c|c|c|}
\hline \multirow{2}{*}{\multicolumn{3}{|c|}{$\begin{array}{l}\text { Location No. and Name } \\
\text { Max } \\
\text { Min }\end{array}$}} & \multicolumn{3}{|c|}{ Soil thickness $(\mathrm{cm})$} & \multicolumn{3}{|c|}{ Epikarst thickness (m) } & \multirow{3}{*}{$\begin{array}{c}\begin{array}{c}\text { Number of } \\
\text { measure- } \\
\text { ments }\end{array} \\
5\end{array}$} \\
\hline & & & \multirow{2}{*}{$\begin{array}{c}\text { Average } \\
12.8\end{array}$} & \multirow{2}{*}{$\begin{array}{r}\text { Max } \\
3.3\end{array}$} & \multirow{2}{*}{$\begin{array}{r}\text { Min } \\
8.0\end{array}$} & \multirow{2}{*}{$\begin{array}{c}\text { Average } \\
6.5\end{array}$} & \multirow[b]{2}{*}{2} & \multirow[b]{2}{*}{4.25} & \\
\hline$A$ & Shairbagh & \multirow{3}{*}{ 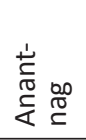 } & & & & & & & \\
\hline B & Shirpora & & 32.2 & 8.6 & 20.4 & 8 & 3 & 5.5 & 4 \\
\hline $\mathrm{C}$ & Kadipora & & 7.2 & 2.6 & 4.9 & 2 & 1.5 & 2 & 2 \\
\hline $\mathrm{F}$ & Keherbal & & 8.3 & 3.1 & 5.7 & 1 & 1 & 1.5 & 3 \\
\hline G & Mattan & & 34.2 & 8 & 21.1 & 9 & 3 & 7 & 1 \\
\hline $\mathrm{H}$ & Bumzoo & & 13.7 & 1.8 & 7.7 & 16 & 4 & 10 & 6 \\
\hline I & Hatmurah & & 9.2 & 3.8 & 6.5 & 2 & 0.40 & 1.20 & 4 \\
\hline J & Wantrag & & 12 & 3.4 & 7.7 & 2 & 1 & 1.5 & 2 \\
\hline $\mathrm{K}$ & Khetricheck & & 1 & 0.8 & 0.9 & 0.85 & - & 0.85 & 3 \\
\hline $\mathrm{L}$ & Achabal & & 16 & 3.4 & 9.7 & 6.2 & 3 & 4 & 4 \\
\hline$M$ & Ruinpur & & 7 & 1.4 & 4.2 & 0.2 & 0.3 & 2.25 & 2 \\
\hline
\end{tabular}


with respect to altitude. Field observations suggested that water action alone might not have been responsible for the diversity of this feature, but other environmental conditions, such as slope and soil cover, seem to have played substantial roles in their formation. The depths of these channels are 6 to $15 \mathrm{~cm}$, and they extend from 1 to $3 \mathrm{~m}$ in length, having a width of 2 to $10 \mathrm{~cm}$, typically with rounded and flat bottom (Fig. 5d). The uniform distribution of runnel depths and widths imparts a sort of regular pattern to flute morphology. The morphological variation with respect to altitude indicates diverse environments of karstification (Fig. 5). The evolutionary trend of this type of karren in the area suggest the predominant role of chemical weathering.

\section{PITS AND SOLUTIONAL PANS}

The dissolution and deposition of calcite in the form of solutional feature has been observed at villages like, Shirpora (N $33^{\circ} 43^{\prime} 37^{\prime \prime}$ and E $\left.75^{\circ} 10^{\prime} 43^{\prime \prime}\right)$, Brakpora (N $33^{\circ}$

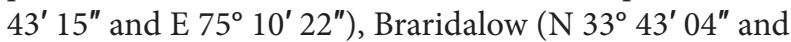
E $\left.75^{\circ} 10^{\prime} 37^{\prime \prime}\right)$, and Khan Mohalla (N 33 $41^{\prime} 22^{\prime \prime}$ and E $\left.75^{\circ} 14^{\prime} 11^{\prime \prime}\right)$. The width of these features varied from 1 to $5 \mathrm{~cm}$ for solutional pans and from 1 to $3 \mathrm{~cm}$ for pits. The pits are clustered in groups, irregular, separated by thin sharp edges and are coupled with organic activity, thus giving the carious appearance to the rock surfaces (Fig. 6). Decaying of organic matter seems to have enhanced chemical weathering and continued to develop and deepen them into hollow pits.
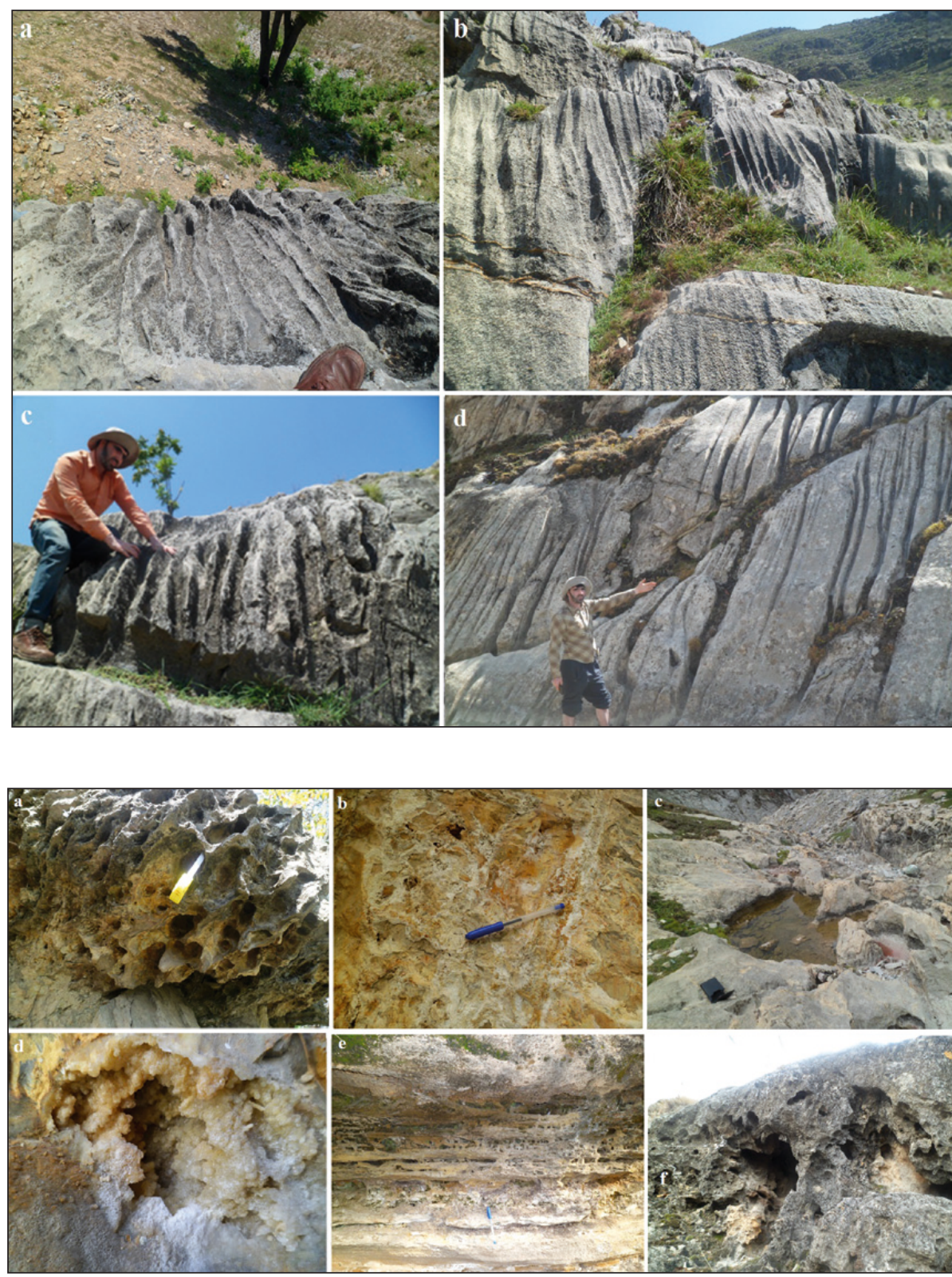

Fig. 5: Karrenfields (Rillenkarren) of different shapes and orientations, identified at different locations/villages of Liddar catchment; (a) Brakpora (b) Keherbal (c) Shirpora and (d) near Sheshnag (Rinnenkarren) (Photo: G. Jeelani \& R. A. Shah).

Fig. 6: Dissolution features (pits and solutional pans) developed at different locations/villages in the Liddar and Bringi catchments; (a, f) Shairbagh (b) Shirpora (c) Adigam (d) Brakpora (e) Khanmohalla (Photo: R. A. Shah). 
DOLINES AND OTHER CIRCULAR DEPRESSIONS

Dolines and other circular depressions are often referred to as the "diagnostic features of karst" (e.g., Ford \& Williams 2007). Towards the eastern part of the study area, at the top of Mattan and Anantnag karst ridge, there are seven small dolines and other circular depressions of varying size and shape (Fig. 7; Tab. 2). The depressions are covered with thin soil (Fig. 7a, b, c, d). The floors of these depressions are flat and retain a residuum from the weathering processes. Besides this, one collapsed roof ranging in diameter from 3 to $7 \mathrm{~m}$ exceeding in depth from 15 to $35 \mathrm{~m}$ was also identified at Keherbal.

\section{SINKS / LOSING STREAMS}

Groups of sinks were identified along the banks of Bringi stream, East Liddar and Langinalla streams in Liddar and Bringi catchments (Fig. 7e, f). The sinks are running through the bedding and joint planes containing numerous anastomotic conduits, typically from 0.2 to $1 \mathrm{~m}$ in width and may therefore form the potential dominant flow routes. It was observed that water from these features is directed towards the karst ridges. A reduction in discharge was noticed along the course of the Bringi, East Liddar and Langinalla streams at various locations, such as Adigam, Dailgam, Gadol, Zajibal, Upper Mirhai and Langnai. Bhat \& Jeelani (2015) and Shah et al. 2017) carried out some dye test and confirmed the hydrological connectivity between the stream sinks (i.e., R, P, V) with some of the karst springs (i.e., S6, S7 and S9) (Fig. 3; Tabs. 2, 3). Because discharge was measured at both up and down stream sinks, 60-90\% recharge occurs through stream sinks.
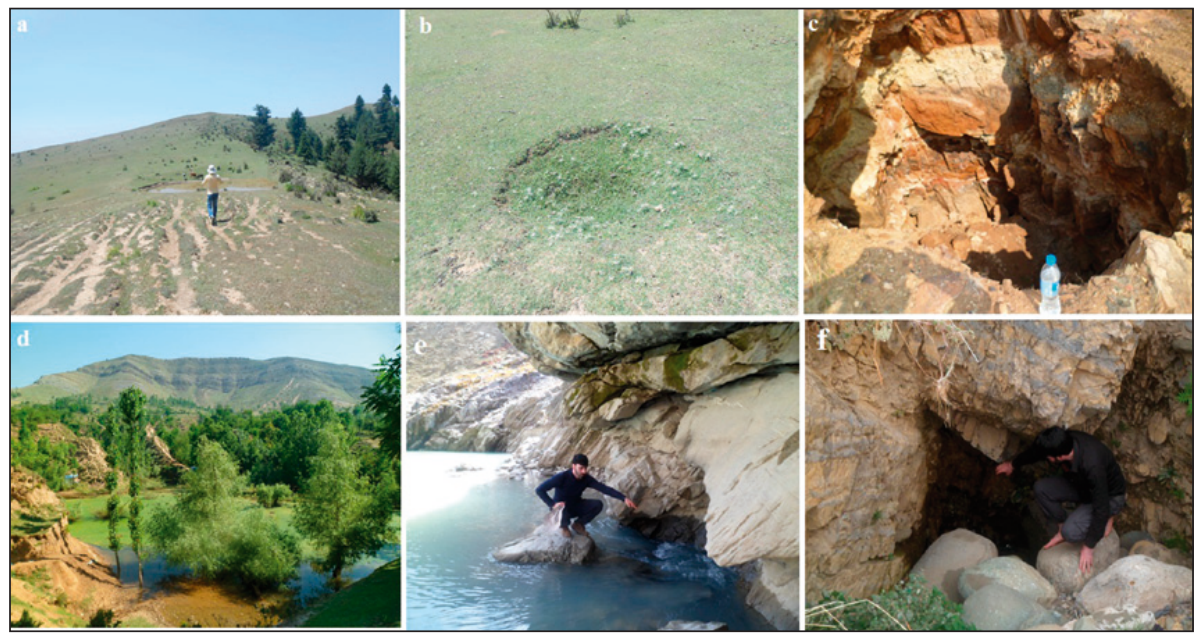

Fig. 7: Dolines/sinkholes along Keherbal-Khetricheck transect at different locations/villages in Liddar watershed; Wantrag (a, b) Keherbal (c), Khetricheck (d). Sinking points along East Liddar and Bringi streams near Sheshnag Lake (d), Dailgam and Adigam villages (f) (Photo: R. A. Shah)

Tab. 2: Statistical summary of the major karst springs of the study region. The location of springs is given in Fig. 3. (Note: "*” represents warm springs.)

\begin{tabular}{|c|c|c|c|c|c|c|}
\hline \multirow{2}{*}{ Catchment } & \multicolumn{2}{|r|}{ Springs } & \multirow{2}{*}{$\begin{array}{c}\text { Altitude (m) } \\
\text { asl }\end{array}$} & \multirow{2}{*}{$\begin{array}{l}\text { Mean annual } \\
\text { Min (L s-1) }\end{array}$} & \multirow{2}{*}{$\begin{array}{l}\text { Mean annual } \\
\text { Max (L s-1) }\end{array}$} & \multirow{2}{*}{$\begin{array}{l}\text { Average (L } \\
\mathrm{s}-1)\end{array}$} \\
\hline & No. & Name & & & & \\
\hline \multirow{4}{*}{ Kuthar } & S1 & Malakhnag* & 1615 & 5 & 10 & 9 \\
\hline & $\mathrm{S} 2$ & Gujnag* & 1620 & 1 & 3 & 2 \\
\hline & S3 & Hamalnag* & 1622 & 2 & 4 & 2.8 \\
\hline & S4 & Dauidnag & 1800 & 4 & 16 & 11 \\
\hline \multirow{2}{*}{ Liddar } & S5 & Andernag & 1605 & 70 & 190 & 131 \\
\hline & S6 & Martandnag & 1620 & 340 & 930 & 514 \\
\hline \multirow{3}{*}{ Bringi } & S7 & Achabalnag & 1700 & 600 & 2800 & 800 \\
\hline & S8 & Kongamnag* & 1730 & 10 & 20 & 15 \\
\hline & S9 & Kokernag & 1935 & 940 & 3380 & 1944 \\
\hline \multirow{4}{*}{ Sandran } & $\mathrm{S} 10$ & Verinag & 1880 & 480 & 2430 & 1166 \\
\hline & $\mathrm{S} 11$ & Kulamchinarnag & 1730 & 110 & 430 & 212 \\
\hline & $\mathrm{S} 12$ & Panzethnag & 1728 & 2200 & 3460 & 2666 \\
\hline & $\mathrm{S} 13$ & Vetistanag & 1820 & 280 & 530 & 420 \\
\hline
\end{tabular}



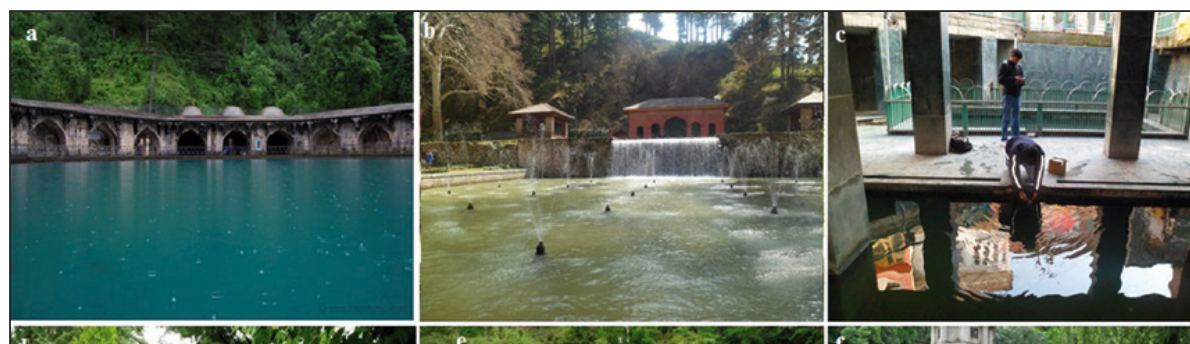

Fig. 8: Major karst springs (nags) of Kashmir Valley; (a) Verinag (b) Achabalnag (c) Malakhnag (d) Kokernag (e) Martandnag ( $f$ ) Andernag. The location of these springs is shown on Fig. 3 (Photo: G. Jeelani \& R. A. Shah).

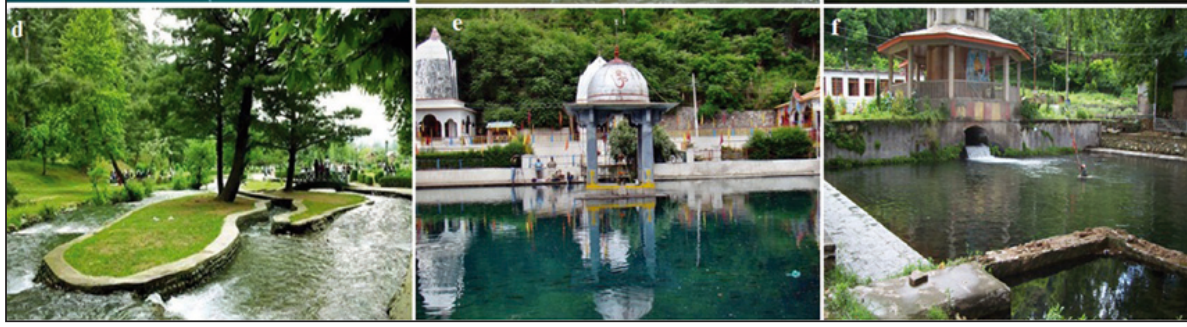

\section{KARST SPRINGS}

Large karst springs (in local language: nag) are the most prominent karst hydrological features in the study area. Fifteen important springs were identified, with discharge ranging from few liters to more than $3000 \mathrm{~L} \mathrm{~s}^{-1}$ (Tab. 2). The karst springs of the area have been categorized into two types on the basis of their significant differences in water temperature: cold $\left(9-14{ }^{\circ} \mathrm{C}\right)$ and warm $\left(20-25^{\circ} \mathrm{C}\right)$ karst springs (Jeelani 2005). Tab. 2 presents a statistical summary of springs in the study area, including location, altitude, minimum, maximum and average discharge. The springs located in Kuthar catchment are warm springs, excluding Dauidnag. The man-made modification and construction of buildings at Martandnag, Andernag, Achabalnag and Verinag has led to hide the real orifice of these springs (Fig. 8).

Hydrographic analysis suggests that the karst springs are perennial. The discharge of cold springs is highly variable, whereas warm springs showed low and almost steady flow rates (Fig. 9b, c). It was observed that cold springs showed faster hydraulic response to hydrologic events and stronger seasonal variability than warm springs. Air temperature showed an influence on the hydrological behaviour of all karst springs, particularly cold springs. The increase of discharge in cold springs from March to October and subsequent decrease from November to January correspond to gradual rises and falls in ambient temperature (Fig. 9a, b). We also noticed brief discharge spikes and a rapid recession in cold karst springs soon after rain events. The lower and relatively uniform discharge of warm springs (Fig. 9c) indicates a weak response to input signals, maybe due to deep circulation of groundwater within the Kuthar catchment, where these warm karst springs exist. This is a good preliminary indicator of the nature of the aquifer pattern, extent of subsurface karsti- fication and recharge area. The highest discharge of karst springs was observed in late spring and summer seasons (from April to July), whereas minimum discharge was recorded during winter and late autumn seasons (from November to February), thus demonstrate the influence

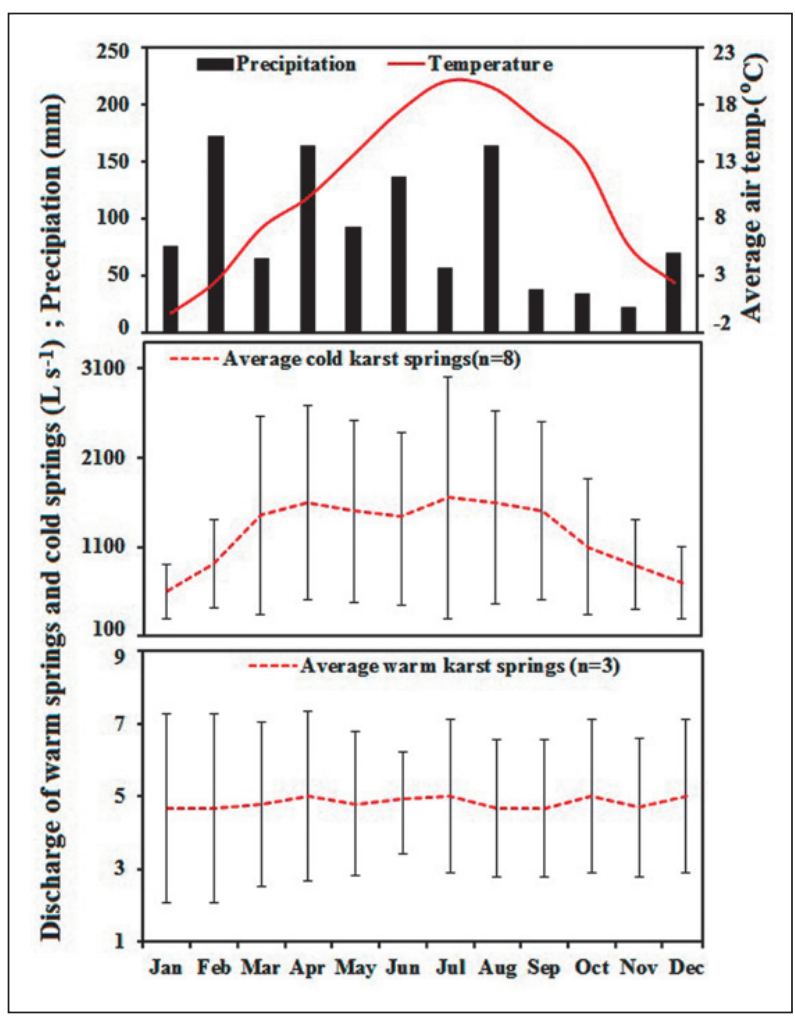

Fig. 9: Monthly hydrographs of cold and warm springs (with error bars representing standard deviation) and their relation with ambient temperature and precipitation measured at Pahalgam weather station (Source: IMD, Srinagar). 
of snow and/or glacier melt, which is dominant source of recharge in the region (Jeelani 2008; Jeelani \& Shah 2016). The initial increase of discharge (from March to May) can be attributed to gradual snowmelt. In summer and autumn (from June to October), higher air temperature increases the degree of snowmelt, and provides sufficient water to recharge the karst springs. Whereas, in winter months, the lower air temperature stops and/or reduce the melting processes and thereby lower discharge (aquifer storage or stream base flow) is attained in karst springs. The perennial nature and fluctuating discharge of the cold karst springs from daily or seasonal to annual scales indicate extensive development of karstification and a high productivity of the karst aquifers in the region. However, the short travel time from few days to weeks' time and rapid flow through trunk conduits (Shah et al. 2017) make these springs highly vulnerable. In context to this, the study recommend that recharge areas of the springs must be protected, restricted and conserved from human activities.

\section{CAVE DISTRIBUTION AND THEIR CHARACTERISTICS}

Caves and subsurface drainage networks are the only geomorphic features where all stages of solution and erosion can remain preserved (Palmer 1991; Ford \& Williams 2007). Therefore, detailed understanding of subsurface conduits and cave development is essential to reconstruct the geomorphic landscape evolution of the region. It is important to note that the number and length of caves in a particular region always reflects the current level of cave exploration, which is rather limited in the study area. During the field work, various relict

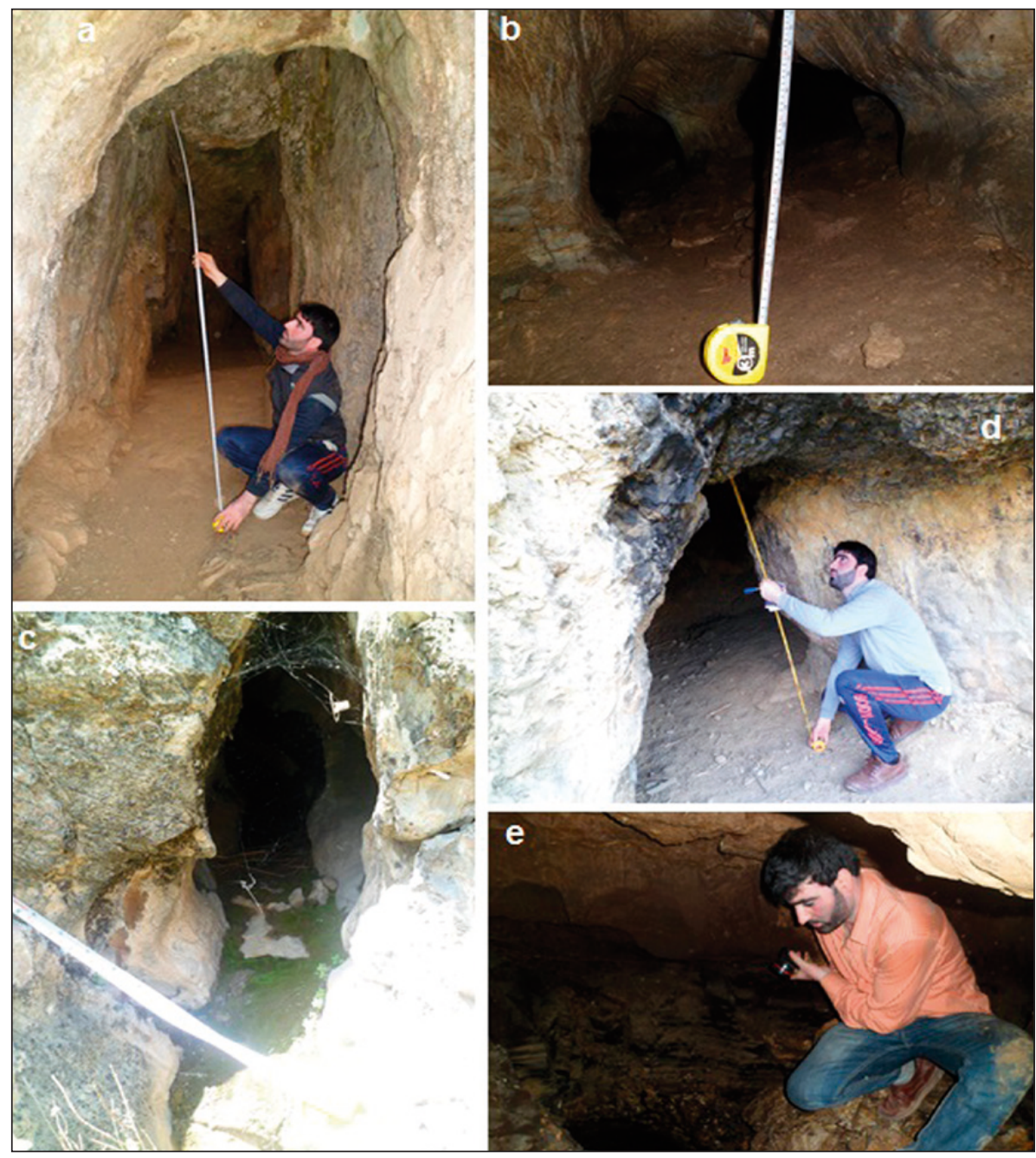

Fig. 10: Cavern development in Liddar and Bringi karst catchment areas; Bumzoo ( $a, b$ and $c)$ and Shairbagh (d). The active conduits filled with water indicate current water table at Braridalow village (e) (Photo: G. Jeelani \& R. A. Shah). 
phreatic caves and subsurface conduits of different scales, shapes and orientations distributed at different locations/ villages were identified (Figs. 10, 11). The longest caves so far identified are the Bumzoo Bat Cave (C1) and Aishmuqam Cave (C8), the statistics of which are shown in Tab. 3. The Bumzoo Bat cave has been traversed up to 80 $\mathrm{m}$ and seems to extend further ahead. A few meters away of the major cave is the next phreatic cave, named locally as Temple cave (C2). This cave is $15 \mathrm{~m}$ long and comprises a single chamber. A similar type of cave was identified at Aishmuqam, $10 \mathrm{~km}$ away from Anantnag Town. The cave is $25 \mathrm{~m}$ long and has been traversed up to full length. $\mathrm{C} 2$ and $\mathrm{C} 8$ caves display extensive human modification. There is archeological evidence that these caves have provided suitable environments for human residence.

The caves display solutional pockets, abundance of roof pedants, and anastomosing channels along joints and bedding planes. The only vadose activity observed was some vertical fluting on passage walls and inactive speleothem depositions of unknown age. Active saturated conduits (e.g., C6) were observed at various locations/ villages including Shairbagh, Brakpora, Braridalow and Achabal.
To assess the role of geological structures on cave development, strike and dip of the bedding and joint planes and the orientation of the caves and conduits were measured during fieldwork. The orientation of caves and conduits are presented in Tab. 2. The structural orientation of lineaments was extracted using Landsat satellite imagery (Fig. 12). The results suggest that conduits/caves are controlled by the pattern and density of joints in the carbonate units and developed significantly along lineaments/joints $\left(40^{\circ}-70^{\circ}\right)$ and bedding planes $\left(120^{\circ}-145^{\circ}\right)$ (Fig. 12). The identified horizontal to sub-horizontal conduits (several meters in length) have narrow entrances. The dry horizontal conduits at different elevations in the same lithostratigraphic unit indicate the level of water table, which seems to have lowered due to the downward development of karstification. Without speleothem dating, the time and history of cave formation in the study area is impossible to determine. However, the phreatic origin and present relict conditions of the caves in the area perched above the valley floor clearly indicates their formation before the existence of Jhelum basin.
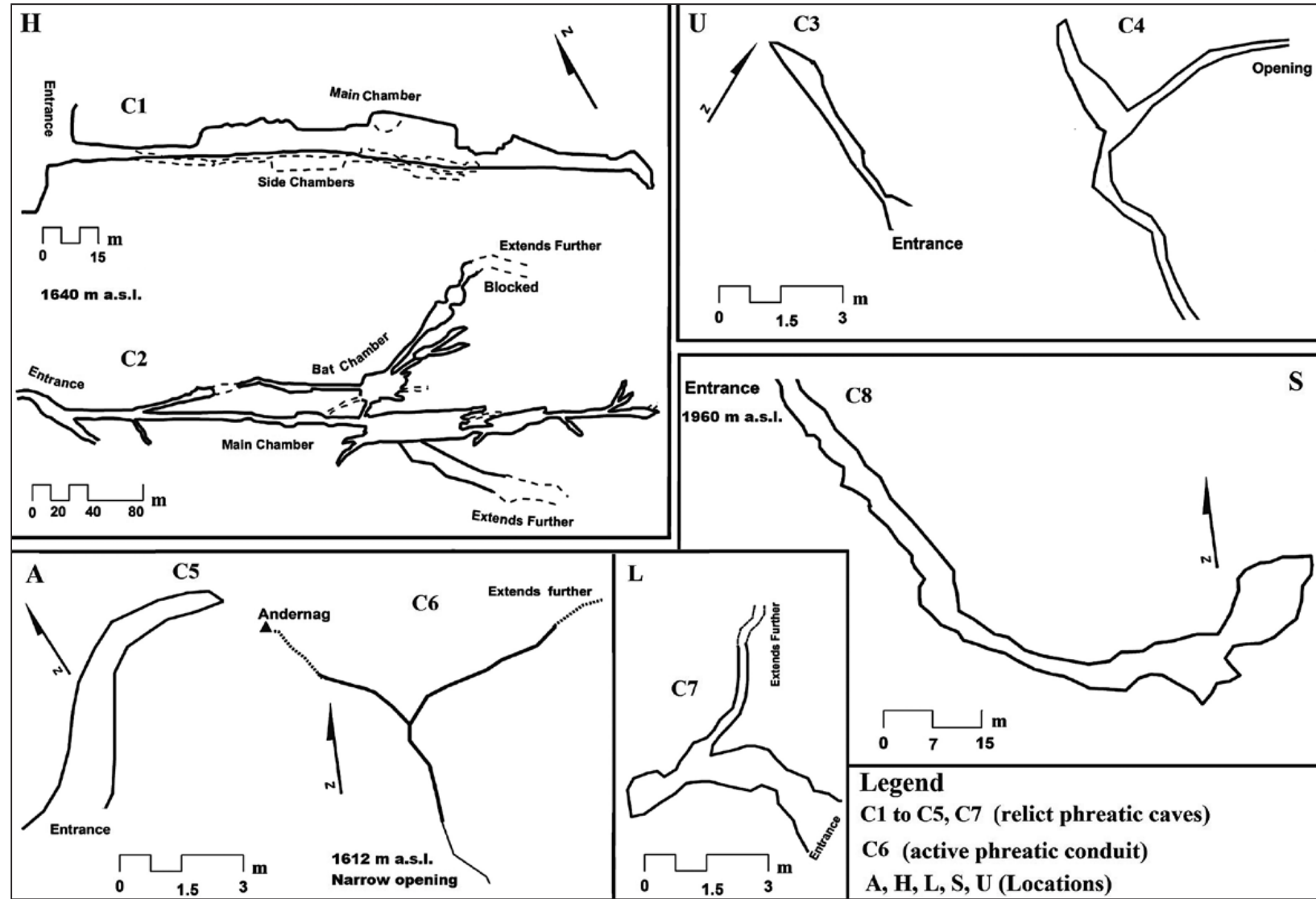

Entrance \ C8

$1960 \mathrm{~m}$ a.s. 


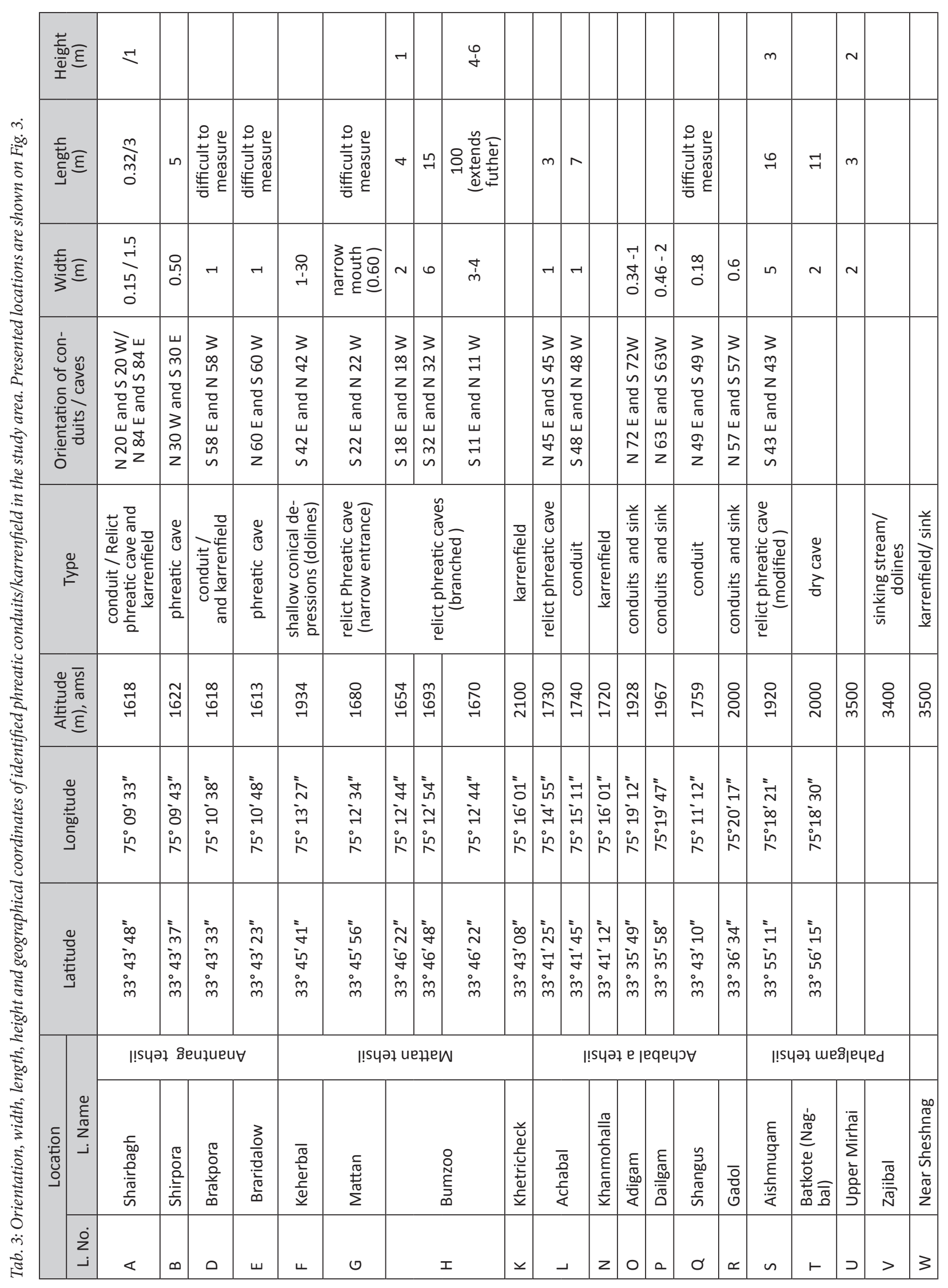




\section{KARST EVOLUTION}

The study area is part of the Tethyan belt and preserves a geological record of the Himalayan orogenesis as well as volcanic formations deposited due to long lasting powerful tectonic activity (Bhat 1982; Burbank \& Johnson 1983; Yin 2006). In Kashmir Valley, imprints of these tectonic episodes are well preserved in the form of various geomorphic landforms (Dar et al. 2014; Alam et al. 2015).

Broadly speaking, in the Mid-Cretaceous the disappearance of the Post-Triassic Sea in the Kashmir region (Saxena 1976; Bhat 1982) led to a thick pile of marine sedimentation, particularly in eastern margins of Kashmir (Fuchs \& Grupta 1971; Wadia 1931, 1975; Bhat 1982), where these marine deposits display an excellent reference section of the Traissic. However, during the period of non-deposition the Triassic and other older sedimentary successions were subjected to compressional forces, which uplifted and folded these Triassic sediments to a maximum relief in the form of anticlines and synclines (Datta 1983). After a long period of non-deposition, although marine condition never restored but the fluvioglacio-lacustrine environment dominated the Plio-Pleistocene, concealing a great deal of Triassic bed rocks with a fluvio-glacio-lacustrine sedimentary pile (Karewa). The continued tectonic upheavals and climatic oscillations

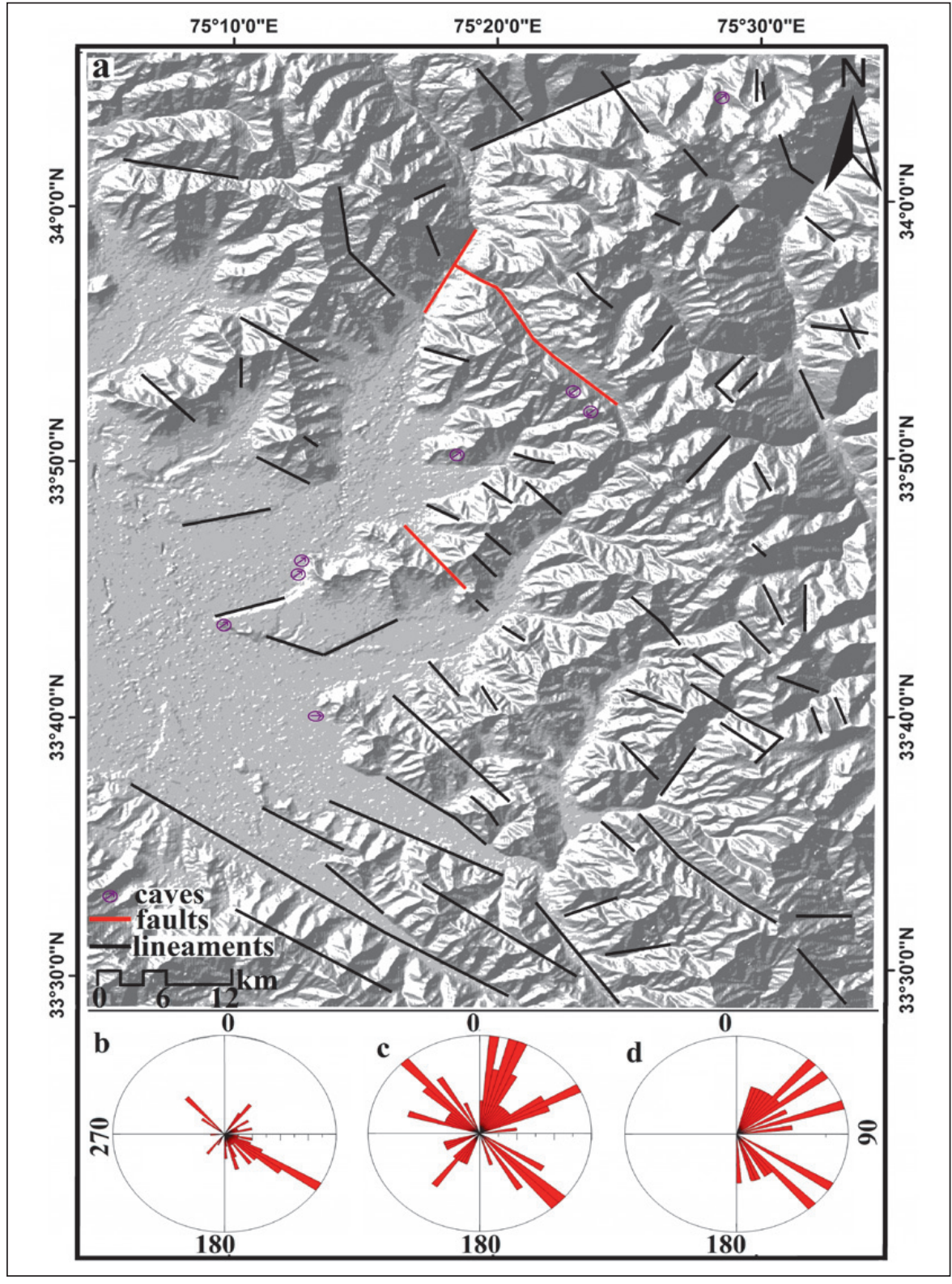

Fig. 12: Lineament map extracted from LANDSAT Satellite imagery (a); Rose diagrams showing orientation of lineaments (b) orientation of joints (c) and subsurface conduits (d) measured in the study area. 
during Plio-Pleistocene changed the primitive morphologic setting by causing a drastic change in the drainage pattern, dissection of the sedimentary formations and erosion of the sediments from these orographic barriers in the region (Burbank 1983). The modern drainage network has been developing since then (Agarwal \& Agarwal 2005). Earlier, the primeval drainage in the region was impounded as a vast lake (De Terra \& Paterson 1939). The uplift and erosion in the Plio-Pleistocene is the dynamic cause governing the processes of karst development in Kashmir Valley. The climatic oscillations (glacial and interglacial) during this period have changed the solution rates and the dominance of either chemical or mechanical erosion. The incision/deepening due to tectonic uplift, combined with climate, dominate the base-level changes of the karst and determined the hydrological network in these karst areas. The geomorphologic and drainage setting of the region reveals that the karstification was controlled mainly by tectonic activity that led to the development of joints and fractures in these carbonate units. Joints and fractures, formed during periods of uplift, have governed the orientation of subsurface karst geomorphic features and increased the secondary permeability in the Triassic Limestone. The progressive dissolution along these geological structures played a key role in the flow patterns in the Triassic Limestones, which later developed a karst conduit drainage network. The importance of major structures in providing water pathways to the karst rocks is reflected in the correlation of sinks and springs, mapped during present study, and faults inferred from geological survey and lin- eament analysis (Middlemiss 1910; Ganju \& Khar 1984). The sink points along the streams, such as the AdigamDailgam sink, Gadol sink along Bringi stream in Bringi catchment, sinks along East Liddar and Langinalla catchments, display significant morphological expressions.

Based on the tectonic framework of the region and cave development, a qualitative conceptual model showing four phases of karst evolution in the region has been developed (Fig. 13). The model reveals that carbonate rocks in each phase preserved significant relics of environmental change in the form of diverse forms of karrenfields and relict phreatic caves at different elevations which are clearly visible in the study area. However, the present hydrological observation in the study area strongly suggest that the ongoing phreatic karst development and dissolution processes have essentially shifted to deeper levels, which is also supported by the occurrence of thermal springs that point to the existence of deep, regional flow systems (Goldscheider et al. 2010). Combining both phreatic morphology and presently relict nature together, it can be inferred that vertical development initiated by tectonic activity, has caused the water table to drop and pushed karstification downward. This landscape evolution changed the hydrologic conditions from phreatic to vadose and thereby modified the processes of speleogenesis and the characteristics of the caves. Until dating is established, it is difficult to determine the absolute time of karst formation in the region. However, dissolution and deposition of calcite in the form of in the form of solutional features reflect its link with warm and humid conditions, probably during Quaternary.

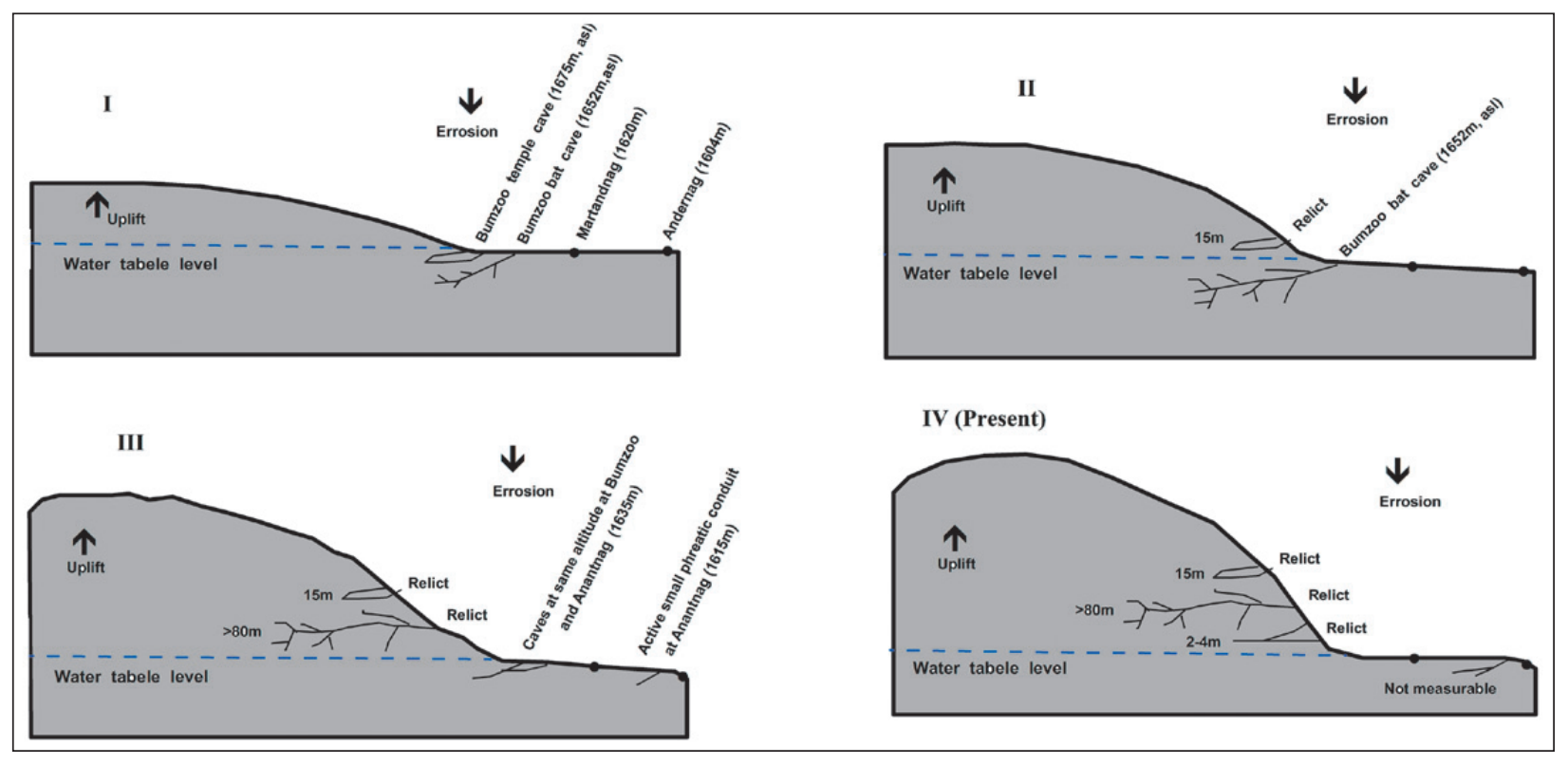

Fig. 13: Conceptual sketches showing the four stages of karst evolution in the region. Each stage reflects the lowering of water table due to related tectonic uplifts. The tectonic episodes pushed the karstification downward and led to phreatic caves at different elevation to dry. 


\section{CONCLUSIONS}

Geomorphic mapping revealed that karst in the Kashmir Valley occurs in the form of dissected ridges. Karst features, such as sinkholes, caverns, conduits, shafts, karrenfields and pits, are well developed in Triassic Limestone towards southern part of Kashmir Valley. Karst springs, including cold and warm (thermal) water springs, are the most prominent karst hydrological features in the Kashmir Valley. The total mean annual discharge of 15 studied springs is $8046 \mathrm{~L} \mathrm{~s}^{-1}$, illustrating the importance of these karst springs as a regional freshwater resource. The study suggested that karstification showed distinct variation with altitude being much more developed towards the valley floor. Caves are controlled by the pat- tern and density of joints in the carbonate units and developed primarily along lineaments, joints and bedding planes. Tectonic uplifts along with erosion of alluvium pushed karstification downwards, which led to dry up of some initial phreatic passages (presently relict). Reconstruction of karst evolution on the basis of morphological, geological and climatological condition of the region suggested that karstification in the Triassic Limestones might have started during Plio-Pleistocene. The study revealed that there is a need for more detailed understanding of subsurface karstification and characterization these karst aquifers in the region for better and sustainable water resources management.

\section{ACKNOWLEDGEMENT}

The research work was funded by Department of Science and Technology (DST) Govt. of India, under the research project, DST No: SERB/F/1554/2012.

\section{REFERENCES}

Agarwal, K.K. \& G.K. Agarwal, 2005: A genetic model for thrust bounded intermontane basin using scaled sandbox analogue models: an example from Karewa Basin, Kashmir Himalayas, India.- International Journal of Earth Science, 94, 47-52.

Alam, A., Ahmad, S., Bhat, M.S. \& B. Ahmad, 2015: Tectonic evolution of Kashmir basin in northwest Himalayas.- Geomorphology, 239, 114-126. DOI: doi.org/10.1016/j.geomorph.2015.03.025

Bakalowicz, M., 2005: Karst groundwater: a challenge for new resources. Hydrogeological Journal, 13, 148160. DOI: doi.org/10.1007/s10040-004-0402-9

Bhat, M.I., 1982: Thermal and tectonic evolution of Kashmir Basin vis-a-vis petroleum prospectus.Tectonophysics, 88, 127-132.

Bhat, N. \& G. Jeelani, 2015: Delineation of the recharge areas and distinguishing the sources of karst springs in Bringi watershed, Kashmir Himalayas using hydrochemistry and environmental isotopes.- Journal of Earth System Science, 24, 8, 1667-1676. DOI: doi.org/10.1007/s12040-015-0629-y

Bögli, A., 1980: Karst hydrology und physical speleology.Springer-Verlag, pp. 284, Berlin Heidelberg.
Brinkmann, R. \& M. Parise, 2012: Karst environments: Problems, management, human impacts, and sustainability - An introduction to the special issue.Journal of Cave \& Karst Studies, 74, 2, 135-136. DOI: doi.org/10.4311/2011JCKS0253

Burbank, D.W. \& G.D. Johnson, 1983: The Late Cenozoic chronologic and stratigraphic development of the Kashmir intermontane basin, Northwestern Himalaya.- Paleogeography, Paleoclimatology, Paleoecology, 43, 205-235. DOI: doi.org/10.1016/00310182(83)90012-3

Burbank, D.W., 1983: The chronology of intermontanebasin development in northwestern Himalaya and the evolution of Northwest Syntaxis.- Earth \& Planetary Science Letters, 64, 77-92.

Chen, Z., Auler, A.S., Bakalowicz. M., Drew, D., Griger, F., Hartmann, J., Jiang, G., Moosdorf, N., Richts, A., Stevanović, Z., Veni, G. \& N. Goldscheider, 2017: The World Karst Aquifer Mapping project: concept, mapping procedure and map of Europe.- Hydrogeology Journal, 25, 3 771-785. DOI: doi.org/10.1007/ s10040-016-1519-3 
COST ACTION-65., 1995: Hydrogeological aspects of groundwater protection in karstic areas-. Final COST action 65 report, Report EUR 16547, Directorate General of Research and Development, pp. 446, Luxembourg.

Coward, J.M., Waltham, A.C. \& R.J. Bowser, 1972: Karst springs in the valley of Kashmir.- Journal of Hydrology, 16, 213-223.

Culver, D.C. \& W.B. White, 2005: Encyclopedia of Caves.Elsevier Academic Press, pp. 654, Amsterdam.

Dar, R.A., Romshoo, S.A., Chandra, R. \& I. Ahmad, 2014: Tectono-geomorphic study of the Karewa Basin of Kashmir Valley.- Journal of Asian Earth Science, 92, 143-156. DOI: doi.org/10.1016/j. jseaes.2014.06.018

Datta, N.K., 1983: Geology, Evolution and hydrocarbon prospects of Kashmir Valley.- Petrolium Asia Journal, 11, 171-179.

De Terra, H. \& T.T. Paterson, 1939: Studies on the Ice Age in India and associated human cultures.- Carnegie Institution, Washington DC, 493, 1-354.

De Waele, J., Plan L. \& P. Audra, 2009: Recent developments in surface and subsurface karst geomorphology: An introduction.- Geomorphology, 106, 1-8. DOI: doi.org/10.1016/j.geomorph.2008.09.023

Field, M.S., 2002: A Lexicon of Cave and Karst Terminology with Special reference to Environmental Karst Hydrology.- U.S. Environmental Protection Agency, pp. 214, Washington D.C.

Ford, D. \& P. Williams, 2007: Karst hydrogeology and geomorphology.- John Wiley and Sons, pp. 554, Chichester.

Fuchs V.G. \& V.J. Gupta, 1971: Paleozoic Stratigraphy of Kashmir, Kishtwar and Chamba: (Punjab Himalayas).- Verh. Geol. B-A. Jahrgang Heft 1, 68-97.

Ganju, J.L. \& B.M. Khar, 1984: Tectonic and hydrocarbon prospects of Kashmir Valley-possible exploration tasks.- Petrolium Asia Journal, 207-216.

Ginés, A., Knez, M., Slabe T. \& W. Dreybrodt, 2009: Karst rock features- karren sculpturing. Založba ZRC/ZRC Publishing, pp. 600, Ljubljana.

Goldscheider, N., Mádl-Szőnyi, J., Erőss, A. \& E. Schill, 2010: Review: Thermal Water Resources in Carbonate Rock Aquifers.- Hydrogeology Journal, 18, 6, 1303-1318. DOI: doi.org/10.1007/s10040-0100611-3

Goldscheider, N. \& D. Drew, 2007: Methods in karst hydrogeology.- Taylor and Francis, pp. 264, London.

Goldscheider, N., 2005: Karst groundwater vulnerability mapping: application of a new method in the Swabian Alb, Germany.- Hydrogeology Journal, 13, 4, 555-564. DOI: doi.org/10.1007/s10040-0030291-3
Goldscheider, N. \& Z. Chen, 2017: World Karst Aquifer Map 1:40,000.- BGR, IAH, KIT \& UNESCO, Berlin, Reading, Karlsruhe \& Paris.

Gunn, J., 2007: Contributory zone definition for groundwater source protection and hazard mitigation in carbonate aquifers.- In: Parise, M. \& J. Gunn (eds.) Natural and anthropogenic hazard in karst Areas, Geological Society of London, 279, pp. 97-109, London. DOI: doi.org/10.1144/SP279.9

Hall, A.B. \& M.J. Day, 2011: Water as a focus of ecotourism in the karst of northern Puerto Rico.- Tourism and Karst Areas, 4, 1, 17-25.

Herak, M. \& V.T. Stringfield, 1972: Karst: Important Karst Regions of the Northern Hemisphere.- Elsevier Publishing Company, pp. 551, New York.

Jamali, M., Moghimi, E. \& Z.A. Jafarpour, 2015: Geomorphology of Karst Features of Shiraz City and Arjan Plain and Development Limitations.- International Journal of Environmental, Chemical, Ecological, Geological and Geophysical Engineering, 9, 1, 25-31.

Jeelani G. \& R.A. Shah, 2016: Delineation of point sources of recharge in karst settings.- In: Kurisu, F., Ramamnathan, A.L., Kazmi A. \& M. Kumar (eds.) Trends in Asian Water in Environmental Science and Technology, International Springer Verlag, pp. 195-209, New Delhi.

Jeelani, G, Deshpande, R.D, Shah, R.A. \& W. Hassan, 2017: Influence of southwest monsoons in Kashmir Valley, western Himalayas.- Isotopes in Environmental \& Health Studies, 53, 4, 400-412. DOI: doi.org/10.108 $0 / 10256016.2016 .1273224$

Jeelani, G., 2005: Chemical quality of the spring waters of Anantnag, Kashmir.- Journal Geological Society of India, 66, 453-462.

Jeelani, G., 2008: Aquifer response to regional climatic variability in a part of Kashmir Himalaya in India.Hydrogeology. Journal, 16, 1625-1633. DOI: doi. org/10.1007/s10040-008-0335-9

Jeelani, G., Shah, R.A., Noble, J. \& R.D. Deshpande, 2016: Estimation of snow and glacier melt contribution to Liddar stream in a mountainous catchment, western Himalaya: an isotopic approach.- Journal of isotopes in Environmental \& Health Studies, 53, 1, 18-35. DOI: doi.org/10.1080/10256016.2016.1186671

Klimchouk, A., 2002: Subsidence Hazards in different Types of Karst: Evolutionary and speleogenetic Approach.- International Journal Speleology, 31, 1/4, 5-18. DOI: doi.org/10.1007/s00254-005-1275-5

Martini, J.E.J., 2000: Dissolution of quartz and silicate minerals.- In: Klimchouk, A.B., Ford, D.C., Palmer, A.N. \& W. Dreybrodt (eds.) Speleogenesis: Evolution of Karst Aquifers, National Speleological Society, Huntsville, Alabama, USA, pp. 171-174., Huntsville. 
Middlemiss, C.S., 1910: Revision of Silurian-Trias sequence of Kashmir.- Record Geological Survey of India, 40, 3, 206-260.

Mylroie, J.R, \& J.E. Mylroie, 2007: Development of the carbonate island karst model.- Journal of Caves \& Karst Studies, 69, 59-75.

Nohegar, A., Norouzi, A. \& M.M. Hosseinzadeh, 2012: The role of karst formations in groundwater resources development.- International Journal of Geology, Earth \& Environmental Sciences, 2, 284-292.

North, L.A., Van-Beynen, P.E \& M. Parise, 2009: Interregional comparison of karst disturbance: Westcentral Florida and southeast Italy.- Journal of Environmental Management, 90, 5, 1770-1781. DOI: doi.org/10.1016/j.jenvman.2008.11.018

Palmer, A.N., 1991: Origin and morphology of caves.Geological Society of America Bulletin, 103, 1-21.

Plan, L., Renetzeder, C., Pavuza, R. \& W. Körner, 2012: A new karren feature: hummocky karren.- International Journal of Speleology, 41, 1, 75-81. DOI: doi. org/10.5038/1827-806X.41.1.8

Radulović, M.M., 2013: A new view on karst genesis.Carbonates and Evaporites, 28, 4, pp. 383-397. DOI: $10.1007 / \mathrm{s} 13146-012-0125-2$

Saxena, M.N., 1976: Orogenic and epirogenic episodes in the northwestern Kashmir Himalayas.- Geotectonia Delle Zone Orogenische Del Kashmir Himalaya, Karakoram-Hindukush-Pamir, Roma 25-77, 293-308.

Shah, R.A., Jeelani, G. \& J. Noble., 2017: Estimating mean residence time of karst groundwater in mountainous basins of Western Himalaya, India.- Hydrological Sciences Journal, 62, 8, 1230-1242. DOI: doi.org /10.1080/02626667.2017.1313420

Stevanović, Z., 2015: Managing karst aquifers, conceptualizion, solutions, impacts.- In: Stevanović, Z. (ed.) Karst aquifers characterization and engineering Series: Professional Practice in Earth Science, Springer International Publishing Switzerland, pp. 403-419.
Stokes, T., Griffiths, P. \& C. Ramsey, 2010: Karst Geomorphology, Hydrology \& Management.- In: Pike, R.G., Redding, T.E., Moore, R.D., Winkler, R.D. \& K.D. Bladon (eds.) Compendium of Forest Hydrology and Geomorphology in British Columbia: Volume 1 of 2, Forum for Research and Extension in Natural Resources, B.C., pp. 373-400, Kamloops.

Thornbury, W.D., 1969: Principles of geomorphology.John Wiley and Sons, Inc. pp. 583.

Vesper, D.J., Loop, C.M. \& W.B. White, 2001: Contaminant transport in karst aquifers: Speleogenesis and Evolution of Karst Aquifers.- Theory \& Applied Karstology, 13-14, 101-111.

Wadia, D.N., 1931: The syntaxis of NW Himalaya, its rocks, tectonics and orogeny.- Record Geological Survey of India, 65, 189-220.

Wadia, D.N., 1975: Geology of India.- Tata McGraw Hill, New Delhi, India, 4th edition, pp., 508.

Williams, P. W., 2008: The role of the epikarst in karst and cave hydrogeology: a review.- International Journal of Speleology, 37, 1, 1-10. DOI: doi. org/10.5038/1827-806X.37.1.1

Yin, A., 2006: Cenozoic tectonic evolution of the Himalayan orogeny as constrained by along-strike variation of structural geometry, exhumation history, and foreland sedimentation.- Earth Science Revision, 76, 1-131. DOI: doi.org/10.1016/j.earscirev.2005.05.004

Zwahlen, F., 2004: Vulnerability and Risk Mapping for the Protection of Carbonate (Karst) Aquifers, ScopeGoals - Results.- European Commission COST Action 620 Directorate-General Science, Research and Development, Luxembourg, pp. 297. 